\title{
Expression of DNA methylation-related proteins in metastatic breast cancer
}

\author{
Y. J. CHA, W. H. JUNG, J. S. KOO* \\ Department of Pathology, Yonsei University College of Medicine, Seoul, South Korea \\ *Correspondence: kjs1976@yuhs.ac
}

Received October 20, 2016 / Accepted December 19, 2016

\begin{abstract}
We aimed to investigate the expression of methylation-related proteins (5-meC and DNMT1) in the metastatic breast cancers of variable sites and its association with clinicopathologic factors. A total of 126 metastatic breast cancers ( 31 bone metastases, 36 brain metastases, 11 liver metastases, 48 lung metastases) were made into tissue microarray and immunohistochemical staining of ER, PR, HER-2, Ki-67, 5-meC, and DNMT1 were performed. Molecular classification was made on the basis of immunohistochemical staining result of ER, PR, HER-2, Ki-67; luminal A, luminal B, HER-2, triple negative breast cancer (TNBC). Methylation-related proteins were differentially expressed based on the metastatic sites. Tumoral and stromal 5-meC showed the lowest expression in the bone metastasis $(P<0.001)$, tumoral DNMT1 showed the least expression in bone metastasis and the highest expression in the brain metastasis $(P<0.001)$. Expression of DNMT1 was correlated with ER negativity $(P=0.004)$, PR negativity $(P=0.011)$, HER-2 positivity $(P=0.016)$, higher Ki-67 labeling indices $(P=0.016)$, and non-luminal A type $(P=0.017)$. DNMT1 positivity was associated with shorter overall survival in bone metastasis $(P=0.017)$ and lung metastasis $(P=0.028)$ by univariate analysis. In conclusion, methylation-related proteins differentially expressed according to the metastatic sites in metastatic breast cancer. Tumoral and stromal 5-meC showed the lowest expression in the bone metastasis. Tumoral DNMT1 expression was low in bone metastasis and highest in brain metastasis.
\end{abstract}

Key words: breast cancer, DNA methylation, DNMT1, 5-meC, metastasis

Cancer cells are different from normal cells in insensitivity to growth inhibitory signals by inhibition of tumor suppressor genes [1]. DNA hypermethylation is one of the key mechanisms of tumor suppressor gene inhibitions. DNA methylation is enhanced by enzymes named DNA methyltransferases (DNMTs) [2], encoded by DNA methyltransferase genes including DNMT1, DNMT2, DNMT3A, and DNMT3B. DNMT1 is the most common and important key maintenance methyltransferase. 5-methylcytosine (5-meC) is a molecule associated with DNMT1, which is a product of DNA methylation, since a methyl group is attached to the 5 ' position of the cytosine ring. In previous study of epigenetic methylation-related protein in breast cancer showed overexpression of DNMT1 and DNMT3a in tumor and its association of poor prognosis [3].

Distant metastasis in breast cancer is one of the causes of high morbidity and mortality. Common metastatic site of breast cancer includes the lung, brain, liver, and bone [4, 5], and the brain and bone metastases have been thoroughly investigated [6-11]. Tumor metastasis occurs via interaction of tumor cells and host tissue, by the processes of adhesion, proteolysis, invasion, and angiogenesis $[5,12]$. However, not every tumor showed similar metastatic pattern, the seed and soil hypothesis has been suggested. It explained that specific tumor (seed) can survive in the specific visceral organ (soil) [13]. Metastatic breast cancer also showed characteristic features based on the metastatic sites. Brain metastasis has been reported to associate with young age, estrogen receptor (ER) negativity, prior lung metastasis, HER-2 overexpression, EGFR overexpression, and basal subtype [8-10], and bone metastasis has been reported to associate with lower histologic grade, ER positivity, ER positivity/progesterone receptor (PR) negativity, strand growth pattern, and presence of fibrotic foci in invasive ductal carcinoma [7, 14, 15]. Therefore, metastatic breast cancers of different metastatic sites are expected to have different characteristics, including expression of epigenetic methylation-related proteins, which is not surveyed yet. We aimed to investigate the expression of methylation-related proteins (5-meC and DNMT1) in the metastatic breast cancers of variable sites and its association with clinicopathologic factors. 


\section{Patients and methods}

Patient selection. Invasive primary breast cancer and metastatic breast cancer to distant organs (liver, lung, brain, and bone) were retrieved from data files of the Department of Pathology of Severance Hospital, Seoul, South Korea. Only patients with a diagnosis of invasive ductal carcinoma were included. A total of 126 cases were included, and 27 cases consisted of paired primary and metastasis carcinomas. All slides were reviewed again and pathologic diagnoses were approved by two pathologists (JSK and WJ). The histological grade was assessed using the Nottingham grading system [16]. This study was approved by the Institutional Review Board of Severance Hospital.

Tissue microarray. On H\&E-stained slides of tumors, a representative area was selected and a corresponding spot was marked on the surface of the paraffin block. Using a biopsy needle, the selected area was punched out and a 3-mm tissue core was placed into a $6 \times 5$ recipient block. Tissue of invasive tumor was extracted. More than 2 tissue cores were extracted to minimize extraction bias. Each tissue core was assigned with a unique tissue microarray location number that was linked to a database containing other clinicopathologic data.

Immunohistochemistry. The antibodies used for immunohistochemistry in this study are shown in Table 1. Three-micrometer paraffin sections were deparaffinized and rehydrated by xylene and alcohol solution. Immunohistochemistry was performed using the Ventana Discovery XT automated stainer (Ventana Medical System, Tucson, AZ, USA). Antigen retrieval was performed using Cell Conditioning 1 (CC1; citrate buffer pH 6.0, Ventana Medical System). Appropriate positive and negative controls for immunohistochemistry were included.

Interpretation of immunohistochemical results. A cutoff value of $1 \%$ or more positively stained nuclei was used to define ER and AR positivity [17]. HER-2 staining was analyzed according to the American Society of Clinical Oncology (ASCO)/College of American Pathologists (CAP) guidelines using the following categories: $0=$ no immunostaining; $1+$ $=$ weak incomplete membranous staining, less than $10 \%$ of tumor cells; $2+=$ complete membranous staining, either uniform or weak in at least $10 \%$ of tumor cells; and $3+=$ uniform intense membranous staining in at least $30 \%$ of tumor cells
[18]. HER-2 immunostaining was considered positive when strong $(3+)$ membranous staining was observed whereas cases with 0 to $1+$ were regarded as negative.

Immunohistochemical staining for 5-meC, DNMT1 was assessed by light microscope by semiquantitative manner. Staining results in cancer cells and stromal cells were assessed as 0 , negative or weak immunostaining in $<1 \%$ of the tumor/ stroma; 1 , focal expression in $1-10 \%$ of tumor/stroma; 2 , positive in $11-50 \%$ of tumor/stroma; and 3, positive in $51-100 \%$ of tumor/stroma. This evaluation was applied to all areas of the tumor in all samples; grade 0,1 were negative and grades 2, 3 were positive [19]. Ki-67 labeling indices (LI) were scored by counting the number of positively stained nuclei and expressed as a percentage of total tumor cells.

Tumor phenotype classification. In this study, we classified breast cancer phenotypes according to the immunohistochemistry results for ER, PR, HER-2 and Ki-67 and FISH results for HER-2 as follows [20]; Luminal A type: ER or/and PR positive and HER-2 negative and Ki-67 LI <14\%, Luminal B type: (HER-2 negative) ER or/and PR positive and HER-2 negative and Ki-67 LI $\geq 14 \%$, (HER-2 positive) ER or/and PR positive and HER-2 overexpressed or/and amplified, HER-2 type: ER and PR negative and HER-2 overexpressed or/and amplified, TNBC type: ER, PR, and HER-2 negative.

Statistical analysis. Data were statistically processed using SPSS for Windows, version 12.0 (SPSS Inc., Chicago, IL, USA). Correlation analysis of immunostaining results between primary breast cancer and metastatic breast cancer were calculated by McNemar test. Student's $t$ and Fisher's exact tests were used to examine any differences in continuous and categorical variables, respectively. A corrected $p$-value and the Bonferroni method were used for multiple comparisons. Statistical significance was assumed when $P<0.05$. KaplanMeier survival curves and log-rank statistics were employed to evaluate time to tumor metastasis and time to survival. Multivariate regression analysis was performed using Cox proportional hazards model.

\section{Results}

Baseline characteristics of patients. A total of 126 cases were composed of 31 bone metastases (24.6\%), 36 brain me-

Table 1. Source, clone, and dilution of antibodies

\begin{tabular}{llc}
\hline Antibody & Company & Clone \\
\hline DNA methylation-related proteins & & Dilution \\
DNMT1 & Abcam, Cambridge, UK & $2 \mathrm{~B} 5$ \\
5-meC & Abcam, Cambridge, UK & $33 \mathrm{D} 3$ \\
Molecular subtype-related proteins & & $1: 200$ \\
ER & Thermo Scientific, San Diego, CA, USA & SP1 \\
PR & DAKO, Glostrup, Denmark & PgR \\
HER-2 & DAKO, Glostrup, Denmark & Polyclonal \\
Ki-67 & Abcam, Cambridge, UK & MIB \\
\hline
\end{tabular}


tastases, 11liver metastases (28.6\%), and 48 lung metastases (38.1\%) Bone metastases and liver metastases showed higher rates of ER and PR positivity $(P<0.001)$. Brain metastases showed higher rate of HER-2 positivity and higher Ki-67 LI ( $P=0.032$ and $P=0.008$, respectively). Luminal A type was common among bone metastases and liver metastases, and TNBC was common among brain metastases and lung metastases $(P<0.001$, Table 2$)$.

Expression of methylation-related proteins in breast cancer metastasis according to metastatic site. In metastatic site, 5-meC expressed in both tumor and stromal cells whereas DNMT1 expressed only in tumor cells (Figure 1). Tumoral 5-meC and stromal 5-meC showed lowest expression in bone metastasis $(P<0.001)$, and tumor DNMT1 showed the least expression in bone meatstases and the highest expression in the brain metastases $(P<0.001$, Figure 2$)$ (Table 3$)$. Normal tissue of all metastatic sites - brain, bone, liver and lung - showed lower DNMT1 expression than tumor cells (Figure 3).

Correlation of expression of methylation-related proteins between primary and metastatic breast cancer according to metastatic site. In 27 paired primary and metastatic cancers, expression of methylation-related proteins was not different between the primary cancer and metastatic cancer. In bone metastases, primary cancers with 5-meC positive in both tumor and stroma were all negative for $5-\mathrm{meC}$ (Table 4).

Table 2. Basal clinicopathologic characteristics of breast cancer metastasis according to the metastatic sites

\begin{tabular}{|c|c|c|c|c|c|c|}
\hline Parameters & Total, $N=126(\%)$ & $\begin{array}{c}\text { Bone metastasis } \\
N=31(\%)\end{array}$ & $\begin{array}{c}\text { Brain metastasis } \\
\quad N=36(\%)\end{array}$ & $\begin{array}{l}\text { Liver metastasis } \\
\quad N=11(\%)\end{array}$ & $\begin{array}{l}\text { Lung metastasis } \\
\qquad N=48(\%)\end{array}$ & $P$ - value \\
\hline Age (years) & & & & & & 0.605 \\
\hline$\leq 50$ & $65(51.6)$ & $17(54.8)$ & $17(47.2)$ & $4(36.4)$ & $27(56.2)$ & \\
\hline$>50$ & $61(48.4)$ & $14(45.2)$ & $19(52.8)$ & $7(63.6)$ & $21(43.8)$ & \\
\hline ER & & & & & & $<0.001$ \\
\hline Negative & $59(46.8)$ & $6(19.4)$ & $25(69.4)$ & $2(18.2)$ & $26(54.2)$ & \\
\hline Positive & $67(53.2)$ & $25(80.6)$ & $11(30.6)$ & $9(81.8)$ & $22(45.8)$ & \\
\hline PR & & & & & & $<0.001$ \\
\hline Negative & $86(68.3)$ & $16(51.6)$ & $35(97.2)$ & $3(27.3)$ & $32(66.7)$ & \\
\hline Positive & $40(31.7)$ & $15(48.4)$ & $1(2.8)$ & $8(72.7)$ & $16(33.3)$ & \\
\hline HER-2 & & & & & & 0.032 \\
\hline Negative & $86(68.3)$ & $25(80.6)$ & $18(50.0)$ & $9(81.8)$ & $34(70.8)$ & \\
\hline Positive & $40(31.7)$ & $6(19.4)$ & $18(50.0)$ & $2(18.2)$ & $14(29.2)$ & \\
\hline Ki-67 LI & & & & & & 0.008 \\
\hline$\leq 14$ & $84(66.7)$ & $27(87.1)$ & $18(50.0)$ & $9(81.8)$ & $30(62.5)$ & \\
\hline$>14$ & $42(33.3)$ & $4(12.9)$ & $18(50.0)$ & $2(18.2)$ & $18(37.5)$ & \\
\hline Molecular subtypes & & & & & & $<0.001$ \\
\hline Luminal A & $44(34.9)$ & $21(67.7)$ & $3(8.3)$ & $6(54.5)$ & $14(29.2)$ & \\
\hline Luminal B & $24(19.0)$ & $5(16.1)$ & $8(22.2)$ & $3(27.3)$ & $8(16.7)$ & \\
\hline HER-2 & $25(19.8)$ & $3(9.7)$ & $12(33.3)$ & $1(9.1)$ & $9(18.8)$ & \\
\hline TNBC & $33(26.2)$ & $2(6.5)$ & $13(36.1)$ & $1(9.1)$ & $17(35.4)$ & \\
\hline Patients death & $41(32.5)$ & $16(51.6)$ & $11(30.6)$ & $4(36.4)$ & $10(20.8)$ & 0.041 \\
\hline
\end{tabular}

Table 3. Expression of methylation-related proteins in tumor cell compartment of breast cancer metastasis according to the metastatic sites

\begin{tabular}{|c|c|c|c|c|c|c|}
\hline Parameters & $\begin{array}{c}\text { Total } \\
N=126(\%)\end{array}$ & $\begin{array}{c}\text { Bone metastasis } \\
\quad N=31(\%)\end{array}$ & $\begin{array}{c}\text { Brain metastasis } \\
N=36(\%)\end{array}$ & $\begin{array}{l}\text { Liver metastasis } \\
\quad N=11(\%)\end{array}$ & $\begin{array}{c}\text { Lung metastasis } \\
\quad N=48(\%)\end{array}$ & $P$ - value \\
\hline 5-meC (T) & & & & & & $<0.001$ \\
\hline Negative & $19(15.1)$ & $16(51.6)$ & $1(2.8)$ & $2(18.2)$ & $0(0.0)$ & \\
\hline Positive & $107(84.9)$ & $15(48.4)$ & 35 (97.2) & $9(81.8)$ & $48(100.0)$ & \\
\hline $5-\mathrm{meC}(\mathrm{S})$ & & & & & & $<0.001$ \\
\hline Negative & $18(14.3)$ & $15(48.4)$ & $1(2.8)$ & $2(18.2)$ & $0(0.0)$ & \\
\hline Positive & $108(85.7)$ & $16(51.6)$ & $35(97.2)$ & $9(81.8)$ & $48(100.0)$ & \\
\hline DNMT1 (T) & & & & & & $<0.001$ \\
\hline Negative & $64(50.8)$ & $22(71.0)$ & $5(13.9)$ & $11(100.0)$ & $26(54.2)$ & \\
\hline Positive & $62(49.2)$ & $9(29.0)$ & $31(86.1)$ & $0(0.0)$ & $22(45.8)$ & \\
\hline
\end{tabular}

T, tumor cell, S, stromal cell 


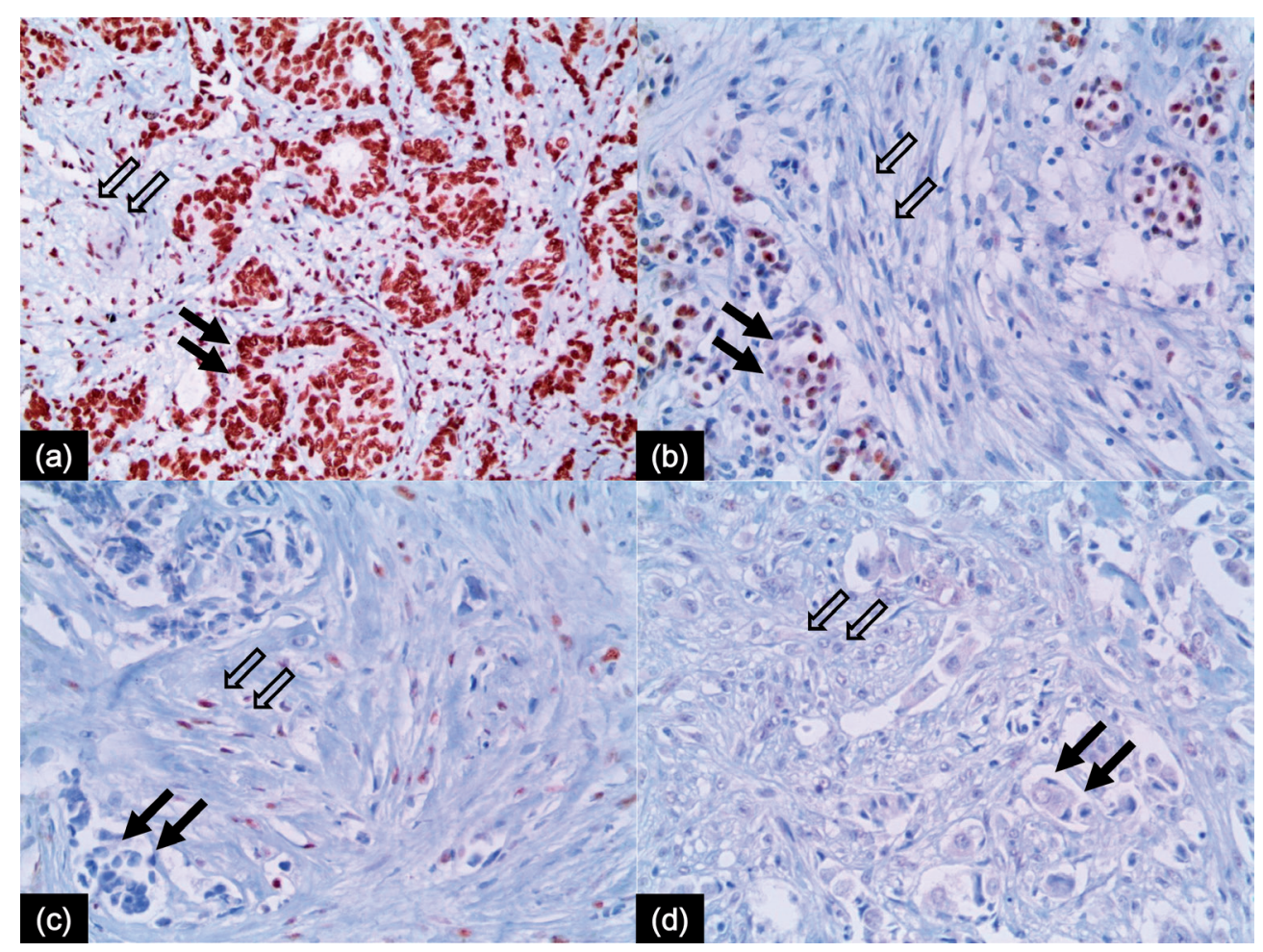

Figure 1. Expression of 5-meC in tumor cells (black arrow) and stromal cells (blank arrow) of metastatic breast cancer. 5-meC is expressed in both tumor and stromal cell (a), only cancer cells (b), only stromal cells (c), or not expressed in both cancer cell and stromal cell (d).

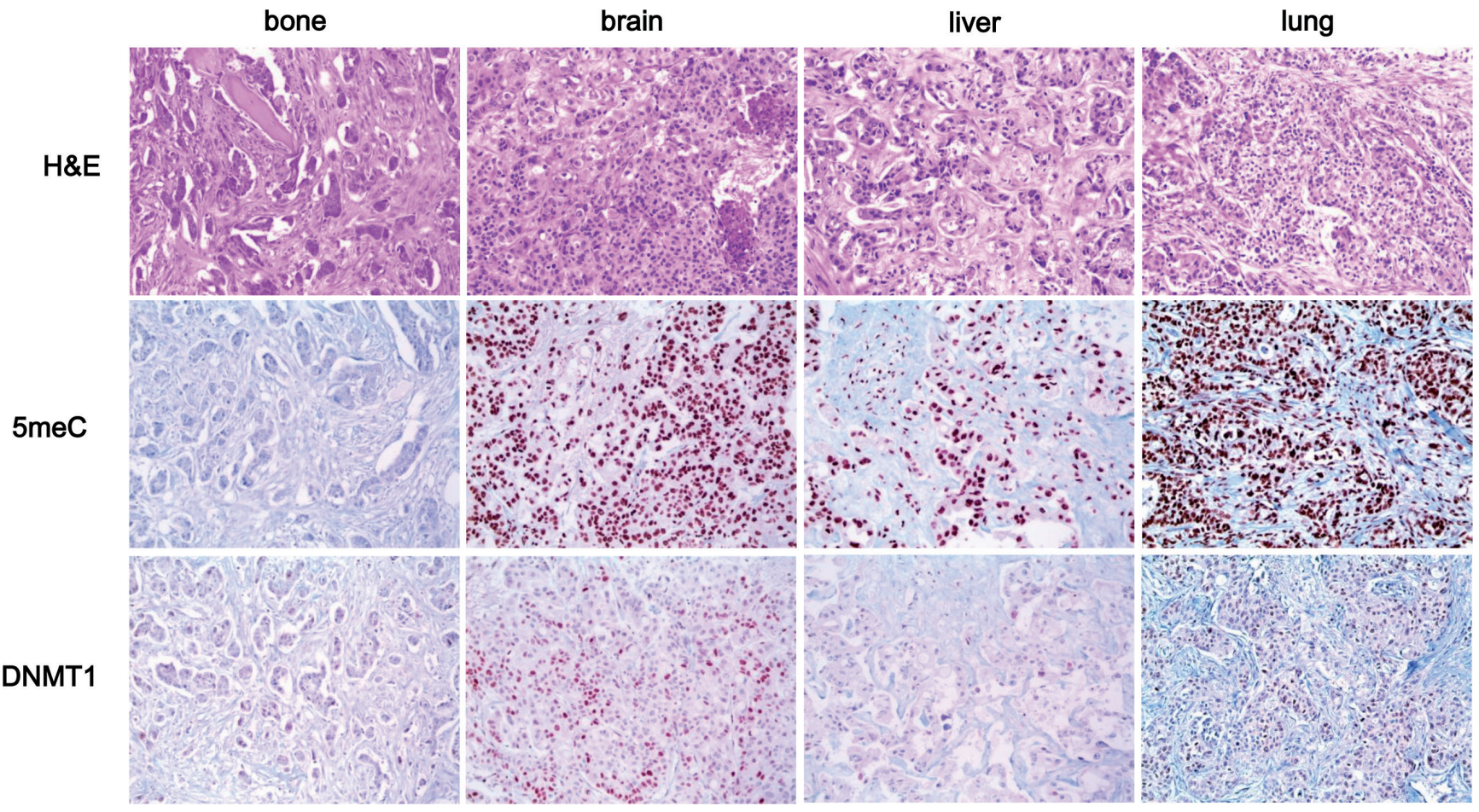

Figure 2. Expression of methylation-related proteins in metastatic breast cancer according to metastatic site. Tumoral 5-meC and stromal 5-meC show the lowest expression in bone metastases, and tumoral DNMT1 is reduced in bone metastases and overexpressed in brain metastasis. 


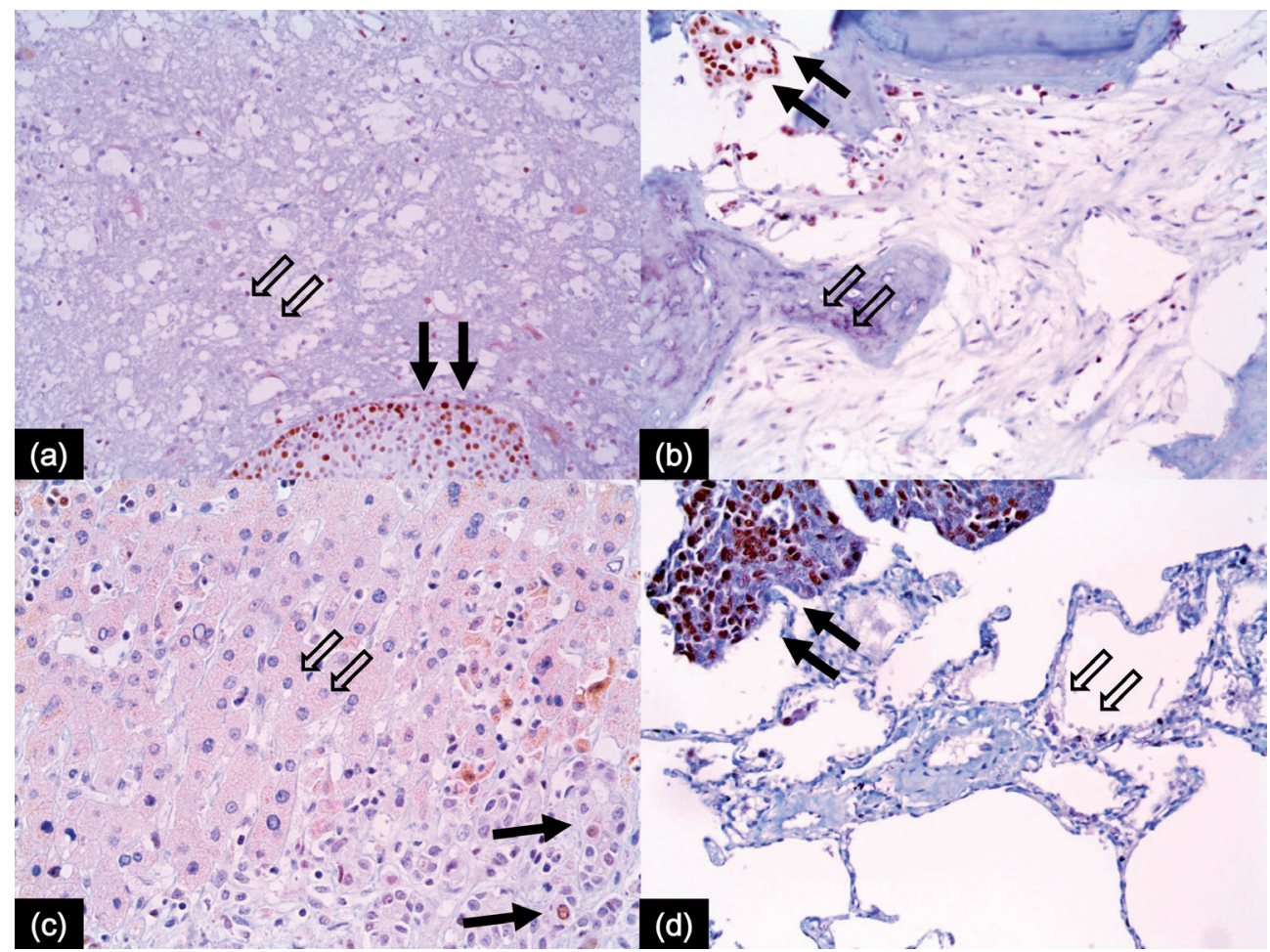

Figure 3. Expression of DNMT1 in normal tissue of brain, bone, liver, and lung. DNMT1 in normal tissue (blank arrows) of brain (a), bone (b), liver (c), and lung (d) shows lower expression than adjacent metastatic tumor cells (black arrows).

Correlation between pathologic factors and expression of methylation-related proteins. DNMT1 expression of metastatic breast cancer was correlated with ER negativity $(P=0.004)$, PR negativity $(P=0.011)$, HER-2 positivity $(P=$
0.016), higher Ki-67 LI $(P=0.016)$, and molecular subtype of non-luminal A type $(P=0.017)$ (Figure 4$)$.

The impact of the expression of methylation-related proteins on patient prognosis. On univariate analysis of total

Table 4. Correlation of expression of methylation-related proteins between primary and metastatic breast cancer according to the metastatic sites

\begin{tabular}{|c|c|c|c|c|c|c|}
\hline Parameters & $\begin{array}{c}\text { Total } \\
N=27(\%)\end{array}$ & $\begin{array}{l}\text { Bone metastasis } \\
\qquad N=5(\%)\end{array}$ & $\begin{array}{c}\text { Brain metastasis } \\
\qquad N=5(\%)\end{array}$ & $\begin{array}{l}\text { Liver metastasis } \\
\qquad N=1(\%)\end{array}$ & $\begin{array}{l}\text { Lung metastasis } \\
\qquad N=16(\%)\end{array}$ & $P$ - value \\
\hline 5-meC (T) & & & & & & 0.063 \\
\hline$(+) \rightarrow(+)$ & $22(81.5)$ & $0(0.0)$ & $5(100.0)$ & $1(100.0)$ & $16(100.0)$ & \\
\hline$(+) \rightarrow(-)$ & $5(18.5)$ & $5(100.0)$ & $0(0.0)$ & $0(0.0)$ & $0(0.0)$ & \\
\hline$(-) \rightarrow(+)$ & $0(0.0)$ & $0(0.0)$ & $0(0.0)$ & $0(0.0)$ & $0(0.0)$ & \\
\hline$(-) \rightarrow(-)$ & $0(0.0)$ & $0(0.0)$ & $0(0.0)$ & $0(0.0)$ & $0(0.0)$ & \\
\hline 5-meC (S) & & & & & & 0.063 \\
\hline$(+) \rightarrow(+)$ & $22(81.5)$ & $0(0.0)$ & $5(100.0)$ & $1(100.0)$ & $16(100.0)$ & \\
\hline$(+) \rightarrow(-)$ & $5(18.5)$ & $5(100.0)$ & $0(0.0)$ & $0(0.0)$ & $0(0.0)$ & \\
\hline$(-) \rightarrow(+)$ & $0(0.0)$ & $0(0.0)$ & $0(0.0)$ & $0(0.0)$ & $0(0.0)$ & \\
\hline$(-) \rightarrow(-)$ & $0(0.0)$ & $0(0.0)$ & $0(0.0)$ & $0(0.0)$ & $0(0.0)$ & \\
\hline DNMT1 (T) & & & & & & 1.000 \\
\hline$(+) \rightarrow(+)$ & $6(22.2)$ & $0(0.0)$ & $4(80.0)$ & $1(100.0)$ & $2(12.5)$ & \\
\hline$(+) \rightarrow(-)$ & $2(7.4)$ & $0(0.0)$ & $1(20.0)$ & $0(0.0)$ & $1(6.2)$ & \\
\hline$(-) \rightarrow(+)$ & $1(3.7)$ & $0(0.0)$ & $0(0.0)$ & $0(0.0)$ & $1(6.2)$ & \\
\hline$(-) \rightarrow(-)$ & $18(66.7)$ & $5(100.0)$ & $0(0.0)$ & $0(0.0)$ & $12(75.0)$ & \\
\hline
\end{tabular}

T, tumor cell, S, stromal cell 

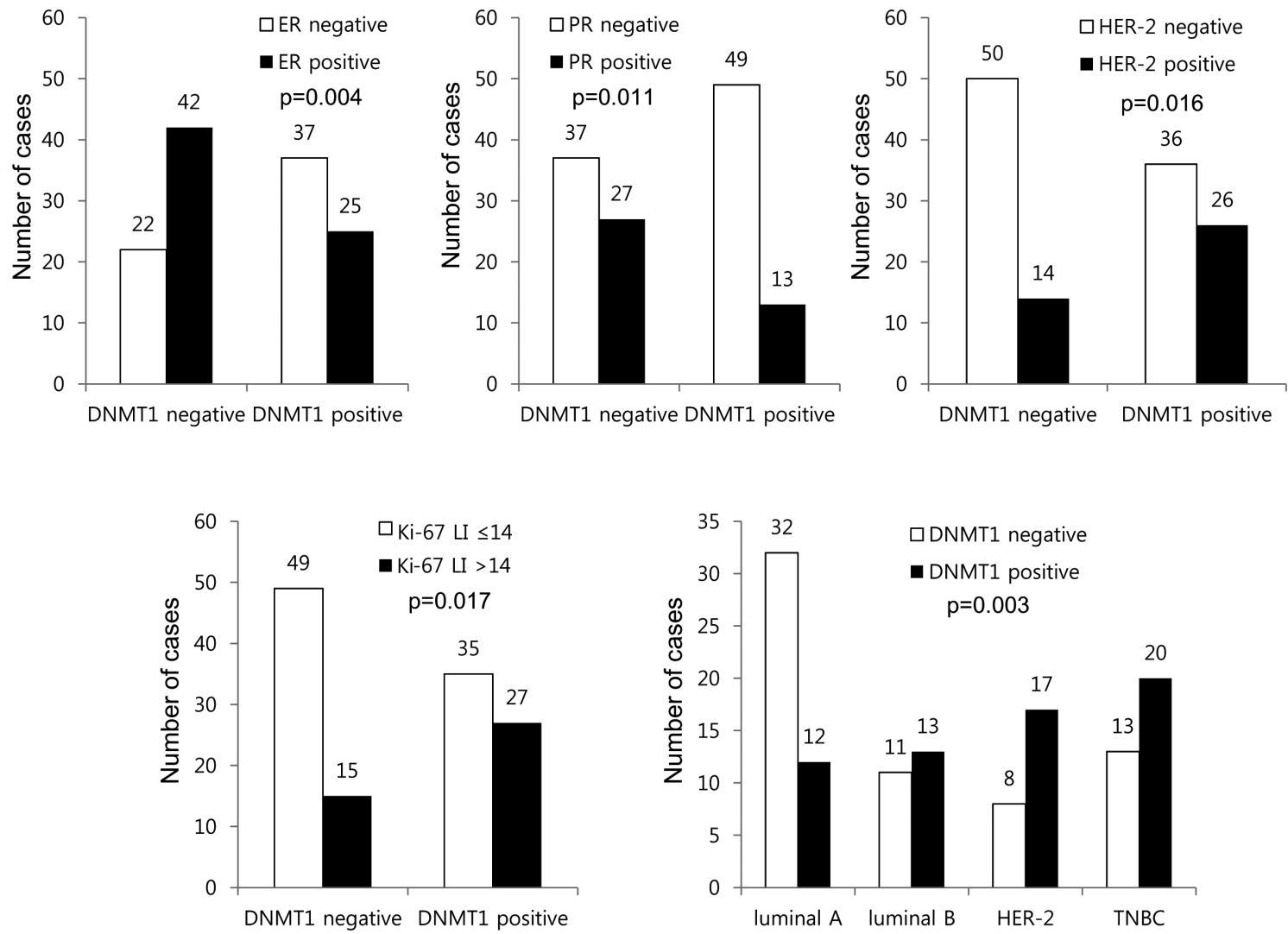

Figure 4. Correlation between pathologic factors and expression of methylation-related proteins in metastatic breast cancer

patients, expression of methylation-related proteins showed no association with shorter overall survival (OS) (Table 5). However, according to the metastatic sites, DMMT1 positivity was associated with shorter $\mathrm{OS}$ in bone metastases $(P=0.017)$, and lung metastases $(P=0.028)$ (Figure 5).

\section{Discussion}

In present study, we evaluated the expression of methylation-related proteins in metastatic breast cancers. Expression of both 5-meC and DNMT1 was low in bone metastases.

Table 5. Univariate analysis of the impact of expression of methylation-related proteins in metastatic breast cancers on overall survival by the log-rank test.

\begin{tabular}{|c|c|c|c|c|c|c|c|c|c|c|}
\hline \multirow[t]{2}{*}{ Parameters } & \multicolumn{2}{|c|}{$\begin{array}{c}\text { Total } \\
N=126(\%)\end{array}$} & \multicolumn{2}{|c|}{$\begin{array}{c}\text { Bone metastasis } \\
\qquad N=31(\%)\end{array}$} & \multicolumn{2}{|c|}{$\begin{array}{c}\text { Brain metastasis } \\
\qquad N=36(\%)\end{array}$} & \multicolumn{2}{|c|}{$\begin{array}{l}\text { Liver metastasis } \\
\qquad N=11(\%)\end{array}$} & \multicolumn{2}{|c|}{$\begin{array}{l}\text { Lung metastasis } \\
\qquad N=48(\%)\end{array}$} \\
\hline & $\begin{array}{c}\text { Mean survival } \\
\text { months } \\
(95 \% \mathrm{CI})\end{array}$ & $P$-value & $\begin{array}{c}\text { Mean survival } \\
\text { months } \\
(95 \% \mathrm{CI})\end{array}$ & $P$ - value & $\begin{array}{c}\text { Mean survival } \\
\text { months } \\
(95 \% \mathrm{CI})\end{array}$ & $P$ - value & $\begin{array}{c}\text { Mean survival } \\
\text { months } \\
(95 \% \mathrm{CI})\end{array}$ & $P$ - value & $\begin{array}{c}\text { Mean survival } \\
\text { months } \\
(95 \% \mathrm{CI})\end{array}$ & $P$ - value \\
\hline 5-meC (T) & & 0.523 & & 0.050 & & $\mathrm{n} / \mathrm{a}$ & & $\mathrm{n} / \mathrm{a}$ & & $\mathrm{n} / \mathrm{a}$ \\
\hline Negative & $105(70-139)$ & & $107(70-143)$ & & $\mathrm{n} / \mathrm{a}$ & & $\mathrm{n} / \mathrm{a}$ & & $\mathrm{n} / \mathrm{a}$ & \\
\hline Positive & $117(100-133)$ & & $48(32-63)$ & & $\mathrm{n} / \mathrm{a}$ & & $\mathrm{n} / \mathrm{a}$ & & $\mathrm{n} / \mathrm{a}$ & \\
\hline 5-meC (S) & & 0.558 & & 0.222 & & $\mathrm{n} / \mathrm{a}$ & & $\mathrm{n} / \mathrm{a}$ & & $\mathrm{n} / \mathrm{a}$ \\
\hline Negative & $87(64-111)$ & & $89(64-114)$ & & $\mathrm{n} / \mathrm{a}$ & & $\mathrm{n} / \mathrm{a}$ & & $\mathrm{n} / \mathrm{a}$ & \\
\hline Positive & $116(100-132)$ & & $64(31-97)$ & & $\mathrm{n} / \mathrm{a}$ & & $\mathrm{n} / \mathrm{a}$ & & $\mathrm{n} / \mathrm{a}$ & \\
\hline DNMT1 (T) & & 0.111 & & 0.017 & & 0.195 & & $\mathrm{n} / \mathrm{a}$ & & 0.028 \\
\hline Negative & $124(104-144)$ & & $104(73-136)$ & & $54(10-98)$ & & $\mathrm{n} / \mathrm{a}$ & & $153(127-179)$ & \\
\hline Positive & $93(71-116)$ & & $41(22-61)$ & & $107(83-131)$ & & $\mathrm{n} / \mathrm{a}$ & & $89(38-140)$ & \\
\hline
\end{tabular}

T, tumor cell, S, stromal cell 

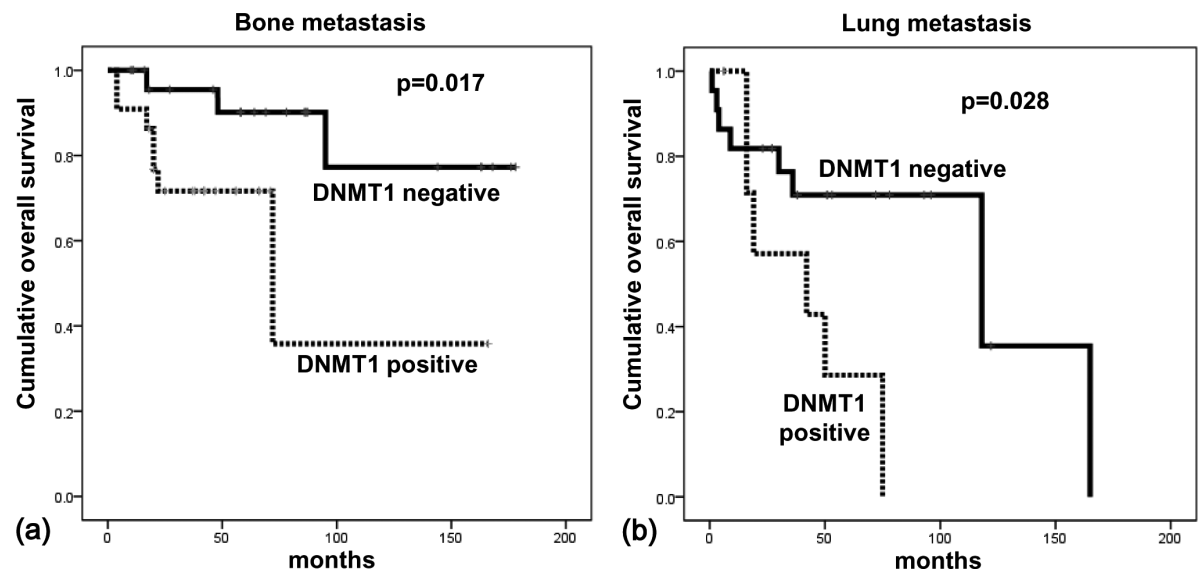

Figure 5. The impact of methylation-related proteins on patient prognosis in bone metastasis (a), and lung metastasis (b)

One of the scenarios for this result would be the association with ER. Yu et al. reported that protein and mRNA levels of DNMT1 were reduced in normal breast specimens and ERa-positive breast cancer specimens compared to the ERanegative breast cancer specimens [3]. In present study, ER status was different according to the metastatic sites, showed the highest positive rate in liver metastases $(81.8 \%)$ followed by bone ( $80.6 \%)$, lung ( $45.8 \%)$, and brain (30.6\%) metastases. DNMT1 positive rate was highest in brain metastases (86.1\%) followed by lung ( $45.8 \%)$, bone $(29.0 \%)$, and liver $(0.0 \%)$ metastases, displaying the opposite order with ER positive rate, that was corroborated by results of previous study. Expression of DNMT1 induces promotor methylation of ERa and results reduction of ER expression [21]. DNMT1 methylates variable genes and suppresses them, which could influence over cancer characteristics. In metastatic breast cancers, BRMS1 (Breast cancer metastasis suppressor 1) [22] and CREB3L1 (cAMPresponsive element-binding protein 3-like protein 1) [22] are methylated and silenced, which could impact on the process of metastasis. Differential expression of methylation-related proteins based on the metastatic sites would be resulted from different tumor microenvironment. Tumor microenvironment (TME) refers the non-tumor, non-transformed elements which are exists in the territory of tumor cells; immune system element (such as macrophages and lymphocytes), blood vessel cells, fibroblast, myofibroblast, mesenchymal stem cells, adipocytes and extracellular matrix (ECM). Most key element of TME is cancer-associated fibroblasts (CAFs) [23]. Previous study demonstrated that IL-6 increases nuclear translocation of DNMT1 by phosphorylation of nuclear localization sequence [24]. Secretion of IL-6 by tumor infiltrating lymphocyte [25] and tumor associated macrophage [26] indicated that tumor stroma would affect the expression of methylation-related proteins. In primary breast cancer, expression of methylationrelated proteins differed according to the phenotype of tumor stroma [27], as well as expression of CAF-related proteins according to the metastatic breast cancers [28], which imply that different phenotype of TME metastatic site may be related with different methylation status and should be clarified on further study. Moreover, intrinsic properties of metastatic sites could result different DNMT1 expression specific to the metastatic sites. In the traumatically injured [29] or hypoxically damaged [30] brain tissue have altered expression of DNMT1. Thus, DNMT1 expression could also be affected by brain metastasis state.

We identified the expression of $5-\mathrm{meC}$ in tumor stroma as well as in tumor cells. Previous studies of epigenetic alteration in CAF reported different specific methylation status between tumor-associated stroma and non-tumor stroma in prostate cancer by methylation pattern analysis [31,32], and global DNA hypomethylation in CAFs has been demonstrated in lung cancer [33]. In present study, 5-meC-negative spindleshaped stromal cells were found in $14.3 \%$ of total cases, and these 5-meC-negative spindle cells could be considered as hypomethylated CAFs. Hypomethylated CAFs were most frequently observed in bone metastases (48.4\%), and global hypomethylation of stromal cells of bone marrow under pathologic condition has been reported [34], thus stromal cell hypomethylation may have association with bone metastases, and further study is required. We observed DNMT1 negativity in tumor stroma, which was compatible with previous study addressed the low expression of DNMT not only in tumor stroma but also in non-tumor stroma [35].

Tumoral DNMT1 expression was associated with shorter OS in present study. This result agreed with previous data that high expression of DNMT1 was correlated with poor prognosis in breast cancer [27], malignant lymphoma [19], renal cell carcinoma [36], pancreatic cancer [37], bladder cancer [38]. MUC1-C oncoprotein could be the link between DNMT1 expression and poor prognosis. DNMT1 overexpression in human breast cancer cells can be induced by MUC1-C oncoprotein [39], and CDH1 gene is one of the downregulated genes by MUC1-C induced DNA methylation $[39,40]$. Higher expression of DNMT1 in tumor cells 
could enhance hypermethylation of $\mathrm{CDH}$ gene, which plays a significant role in cell adhesion. Reduction of cell adhesion would offer tumor cells increased metastatic potential and lead to poor prognosis.

Clinical implication of present study was assessment of epigenetic methylation-related proteins like DNMT1 as a potential therapeutic target for cancer therapy. Endeavors to target DNMT1 in multiple cancers have been explored [41-44], and metastatic breast cancer would be the possible candidate for DNMT1 inhibition. Investigation of treatment response to DNMT1 targeted therapy in metastatic breast cancer is necessary considering the different expression levels of DNMT1 in specific metastasis sites and of which stroma.

In conclusion, methylation-related proteins revealed different expression levels in metastatic breast cancer based on the metastatic sites. 5-meC showed low expression in tumor and stroma of bone metastases, and tumoral DNMT1 showed reduced expression in bone metastases and overexpression in brain metastases.

Acknowledgements: This study was supported by a grant from the National R\&D Program for Cancer Control, Ministry of Health \& Welfare, Republic of Korea (1420080). This research was supported by Basic Science Research Program through the National Research Foundation of Korea (NRF) funded by the Ministry of Science, ICT and Future Planning (2015R1A1A1A05001209).

\section{References}

[1] JONES PA. DNA methylation and cancer. Oncogene 2002; 21: 5358-5360. https://doi.org/10.1038/sj.onc.1205597

[2] SIEDLECKI P, ZIELENKIEWICZ P. Mammalian DNA methyltransferases. Acta Biochim Pol 2006; 53: 245-256.

[3] YU Z, XIAO Q, ZHAO L, REN J, BAI X et al. DNA methyltransferase $1 / 3$ a overexpression in sporadic breast cancer is associated with reduced expression of estrogen receptor-alpha/ breast cancer susceptibility gene 1 and poor prognosis. Mol Carcinog 2015; 54: 707-719. https://doi.org/10.1002/mc.22133

[4] WEIL RJ, PALMIERI DC, BRONDER JL, STARK AM, STEEG PS. Breast cancer metastasis to the central nervous system. Am J Pathol 2005; 167: 913-920. https://doi.org/10.1016/ S0002-9440(10)61180-7

[5] WOODHOUSEEC,CHUAQUIRF,LIOTTALA. Generalmechanisms of metastasis. Cancer 1997; 80: 1529-1537. https://doi. org/10.1002/(SICI)1097-0142(19971015)80:8+<1529::AIDCNCR2>3.0.CO;2-F

[6] ABALI H, CELIK I. High incidence of central nervous system involvement in patients with breast cancer treated with epirubicin and docetaxel. Am J Clin Oncol 2002; 25: 632-633. https://doi.org/10.1097/00000421-200212000-00023

[7] COLLEONI M, O'NEILL A, GOLDHIRSCH A, GELBER $\mathrm{RD}$, BONETTI $\mathrm{M}$ et al. Identifying breast cancer patients at high risk for bone metastases. J Clin Oncol 2000; 18 : 3925-3935.

[8] EVANS AJ, JAMES JJ, CORNFORD EJ, CHAN SY, BURRELL $\mathrm{HC}$ et al. Brain metastases from breast cancer: identification of a high-risk group. Clin Oncol (R Coll Radiol) 2004; 16: 345-349. https://doi.org/10.1016/j.clon.2004.03.012

[9] GAEDCKE J, TRAUB F, MILDE S, WILKENS L, STAN A et al. Predominance of the basal type and HER-2/neu type in brain metastasis from breast cancer. Mod Pathol 2007; 20: 864-870. https://doi.org/10.1038/modpathol.3800830

[10] HICKS DG, SHORT SM, PRESCOTT NL, TARR SM, COLEMAN KA et al. Breast cancers with brain metastases are more likely to be estrogen receptor negative, express the basal cytokeratin CK5/6, and overexpress HER2 or EGFR. Am J Surg Pathol 2006; 30: 1097-1104. https://doi.org/10.1097/01. pas.0000213306.05811.b9

[11] LORINCZ T, TOTH J, BADALIAN G, TIMAR J, SZENDROI M. HER-2/neu genotype of breast cancer may change in bone metastasis. Pathol Oncol Res 2006; 12: 149-152. https://doi. org/10.1007/BF02893361

[12] NICOLSON GL. Organ specificity of tumor metastasis: role of preferential adhesion, invasion and growth of malignant cells at specific secondary sites. Cancer Metastasis Rev 1988; 7: 143-188. https://doi.org/10.1007/BF00046483

[13] PAGET $S$ The distribution of secondary growths in cancer of the breast. Lancet 1889; 133: 571-572. https://doi.org/10.1016/ $\underline{\text { S0140-6736(00)49915-0 }}$

[14] HASEBE T, IMOTO S, YOKOSE T, ISHII G, IWASAKI M et al. Histopathologic factors significantly associated with initial organ-specific metastasis by invasive ductal carcinoma of the breast: a prospective study. Hum Pathol 2008; 39: 681-693. https://doi.org/10.1016/j.humpath.2007.09.012

[15] WEI B, WANG J, BOURNE P, YANG Q, HICKS D et al. Bone metastasis is strongly associated with estrogen receptorpositive/progesterone receptor-negative breast carcinomas. Hum Pathol 2008; 39: 1809-1815. https://doi.org/10.1016/j. humpath.2008.05.010

[16] ELSTON CW, ELLIS IO Pathological prognostic factors in breast cancer. I. The value of histological grade in breast cancer: experience from a large study with long-term follow-up. Histopathology 1991; 19: 403-410. https://doi. org/10.1111/j.1365-2559.1991.tb00229.x

[17] HAMMOND ME, HAYES DF, DOWSETT M, ALLRED DC, HAGERTY KL et al. American Society of Clinical Oncology/ College Of American Pathologists guideline recommendations for immunohistochemical testing of estrogen and progesterone receptors in breast cancer. J Clin Oncol 2010; 28: 2784-2795. https://doi.org/10.1200/JCO.2009.25.6529

[18] WOLFF AC, HAMMOND ME, SCHWARTZ JN, HAGERTY KL, ALLRED DC et al. American Society of Clinical Oncology/College of American Pathologists guideline recommendations for human epidermal growth factor receptor 2 testing in breast cancer. J Clin Oncol 2007; 25: 118-145. https://doi.org/10.1200/JCO.2006.09.2775

[19] ZHAO H, ZHANG LE, GUO S, YUAN T, XIA B et al. Overexpression of DNA methyltransferase 1 as a negative independent prognostic factor in primary gastrointestinal diffuse large B-cell lymphoma treated with CHOP-like regimen and rituximab. Oncol Lett 2015; 9: 2307-2312.

[20] GOLDHIRSCH A, WOOD WC, COATES AS, GELBER RD, THURLIMANN B et al. Strategies for subtypes--dealing with 
the diversity of breast cancer: highlights of the St. Gallen International Expert Consensus on the Primary Therapy of Early Breast Cancer 2011. Ann Oncol 2011; 22: 1736-1747. https://doi.org/10.1093/annonc/mdr304

[21] ZHANG W, CHANG Z, SHI KE, SONG L, CUI LI et al. The correlation between DNMT1 and ERalpha expression and the methylation status of ERalpha, and its clinical significance in breast cancer. Oncol Lett 2016; 11: 1995-2000.

[22] KONG B, LV ZD, WANG Y, JIN LY, DING L et al. Downregulation of BRMS1 by DNA hypermethylation and its association with metastatic progression in triple-negative breast cancer. Int J Clin Exp Pathol 2015; 8: 11076-11083.

[23] FRANCO OE, SHAW AK, STRAND DW, HAYWARD SW. Cancer associated fibroblasts in cancer pathogenesis. Semin Cell Dev Biol 2010; 21: 33-39. https://doi.org/10.1016/j. semcdb.2009.10.010

[24] HODGE DR, CHO E, COPELAND TD, GUSZCZYNSKI T, YANG E et al. IL- 6 enhances the nuclear translocation of DNA cytosine-5-methyltransferase 1 (DNMT1) via phosphorylation of the nuclear localization sequence by the AKT kinase. Cancer Genomics Proteomics 2007; 4: 387-398.

[25] KOVACSOVICS-BANKOWSKI M, CHISHOLM L, VERCELLINI J, TUCKER CG, MONTLER R et al. Detailed characterization of tumor infiltrating lymphocytes in two distinct human solid malignancies show phenotypic similarities. J Immunother Cancer 2014; 2: 38. https://doi.org/10.1186/ s40425-014-0038-9

[26] XU H, LAI W, ZHANG Y, LIU L, LUO X et al. Tumor-associated macrophage-derived IL- 6 and IL- 8 enhance invasive activity of LoVo cells induced by PRL-3 in a KCNN4 channeldependent manner. BMC Cancer 2014; 14: 330. https://doi. org/10.1186/1471-2407-14-330

[27] SHIN E, LEE Y, KOO JS. Differential expression of the epigenetic methylation-related protein DNMT1 by breast cancer molecular subtype and stromal histology. J Transl Med 2016; 14: 87. https://doi.org/10.1186/s12967-016-0840-x

[28] KIM HM, JUNG WH, KOO JS. Expression of cancer-associated fibroblast related proteins in metastatic breast cancer: an immunohistochemical analysis. J Transl Med 2015; 13: 222. https://doi.org/10.1186/s12967-015-0587-9

[29] LUNDBERG J, KARIMI M, VON GERTTEN C, HOLMIN S, EKSTROM TJ et al. Traumatic brain injury induces relocalization of DNA-methyltransferase 1. Neurosci Lett 2009; 457: 8-11. https://doi.org/10.1016/j.neulet.2009.03.105

[30] WU X, SUN J, LI L. Chronic cerebrovascular hypoperfusion affects global DNA methylation and histone acetylation in rat brain. Neurosci Bull 2013; 29: 685-692. https://doi. org/10.1007/s12264-013-1345-8

[31] CUNHA GR, HAYWARD SW, WANG YZ. Role of stroma in carcinogenesis of the prostate. Differentiation 2002; 70: 473-485. https://doi.org/10.1046/j.1432-0436.2002.700902.x

[32] RODRIGUEZ-CANALES J, HANSON JC, TANGREA MA, ERICKSON HS, ALBERT PS et al. Identification of a unique epigenetic sub-microenvironment in prostate cancer. J Pathol 2007; 211: 410-419. https://doi.org/10.1002/path.2133
[33] VIZOSO M, PUIG M, CARMONA FJ, MAQUEDA M, VELASQUEZ A et al. Aberrant DNA methylation in non-small cell lung cancer-associated fibroblasts. Carcinogenesis 2015; 36: 1453-1463. https://doi.org/10.1093/carcin/bgv146

[34] KIM Y, JEKARL DW, KIM J, KWON A, CHOI H et al. Genetic and epigenetic alterations of bone marrow stromal cells in myelodysplastic syndrome and acute myeloid leukemia patients. Stem Cell Res 2015; 14: 177-184. https://doi.org/10.1016/j. scr.2015.01.004

[35] OSTMAN A. Cancer-associated fibroblasts: recent developments and emerging challenges. Semin Cancer Biol 2014; 25: 1-2. https://doi.org/10.1016/j.semcancer.2014.02.004

[36] LI M, WANG Y, SONG Y, BU R, YIN B et al. Aberrant DNA methyltransferase 1 expression in clear cell renal cell carcinoma development and progression. Chin J Cancer Res 2014; 26: 371-381.

[37] ZHANG JJ, ZHU Y, ZHU Y, WU JL, LIANG WB et al. Association of increased DNA methyltransferase expression with carcinogenesis and poor prognosis in pancreatic ductal adenocarcinoma. Clin Transl Oncol 2012; 14: 116-124. https:// doi.org/10.1007/s12094-012-0770-x

[38] WU CT, WU CF, LU CH, LIN CC, CHEN WC et al. Expression and function role of DNA methyltransferase 1 in human bladder cancer. Cancer 2011; 117: 5221-5233. https://doi. org/10.1002/cncr.26150

[39] RAJABI H, TAGDE A, ALAM M, BOUILLEZ A, PITRODA $S$ et al. DNA methylation by DNMT1 and DNMT3b methyltransferases is driven by the MUC1-C oncoprotein in human carcinoma cells. Oncogene 2016; 35: 6439-6445. https://doi. org/10.1038/onc. 2016.180

[40] TAGDE A, RAJABI H, STROOPINSKY D, GALI R, ALAM $\mathrm{M}$ et al. MUC1-C induces DNA methyltransferase 1 and represses tumor suppressor genes in acute myeloid leukemia. Oncotarget 2016; 7: 38974-38987. https://doi.org/10.18632/ oncotarget. 9777

[41] AMATO RJ, STEPHENSON J, HOTTE S, NEMUNAITIS J, BELANGER $\mathrm{K}$ et al. MG98, a second-generation DNMT1 inhibitor, in the treatment of advanced renal cell carcinoma. Cancer Invest 2012; 30: 415-421. https://doi.org/10.3109/07 $\underline{357907.2012 .675381}$

[42] MUTZE K, LANGER R, SCHUMACHER F, BECKER K, OTT $\mathrm{K}$ et al. DNA methyltransferase 1 as a predictive biomarker and potential therapeutic target for chemotherapy in gastric cancer. Eur J Cancer 2011; 47: 1817-1825. https://doi. org/10.1016/j.ejca.2011.02.024

[43] SUBRAMANIAM D, THOMBRE R, DHAR A, ANANT S. DNA methyltransferases: a novel target for prevention and therapy. Front Oncol 2014; 4: 80. https://doi.org/10.3389/ fonc. 2014.00080

[44] THOTTASSERY JV, SAMBANDAM V, ALLAN PW, MADDRY JA, MAXUITENKO YY et al. Novel DNA methyltransferase-1 (DNMT1) depleting anticancer nucleosides, 4'-thio-2'-deoxycytidine and 5-aza-4'-thio-2'-deoxycytidine. Cancer Chemother Pharmacol 2014; 74: 291-302. https://doi. org/10.1007/s00280-014-2503-Z 